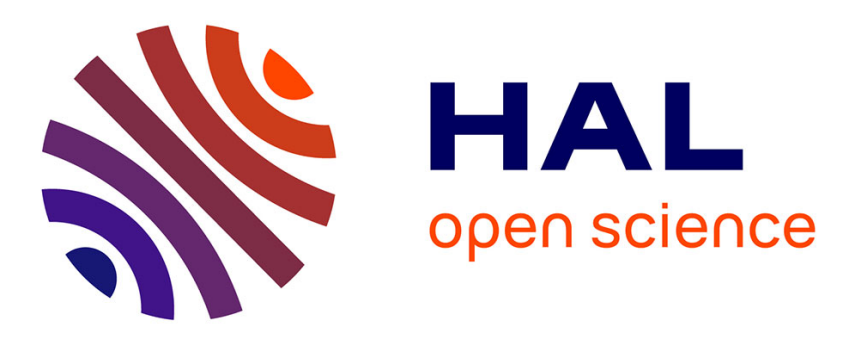

\title{
Innovative building materials for energy performance in buildings
}

\author{
Basma M'Lahfi, Mostafa El Quandil, Driss Amegouz
}

\section{To cite this version:}

Basma M'Lahfi, Mostafa El Quandil, Driss Amegouz. Innovative building materials for energy performance in buildings. IMAT3E'18 International Meeting on Advanced Technologies in Energy and Electrical Engineering, Nov 2018, Fès, Morocco. hal-01952164

\section{HAL Id: hal-01952164 https://hal.science/hal-01952164}

Submitted on 11 Dec 2018

HAL is a multi-disciplinary open access archive for the deposit and dissemination of scientific research documents, whether they are published or not. The documents may come from teaching and research institutions in France or abroad, or from public or private research centers.
L'archive ouverte pluridisciplinaire HAL, est destinée au dépôt et à la diffusion de documents scientifiques de niveau recherche, publiés ou non, émanant des établissements d'enseignement et de recherche français ou étrangers, des laboratoires publics ou privés. 


\section{Innovative building materials for energy performance in buildings \\ *Basma M’LAHFI (1), Mostafa EL QANDIL (1), Driss AMEGOUZ (2) \\ (1) LERDD / FS /University Sidi Mohamed Ben Abdelah - Morocco \\ Email: basma.mlahfi@usmba.ac.ma / mostafelquandil@yahoo.fr \\ (2) LPEDD / EST /University Sidi Mohamed Ben Abdelah - Morocco Email: amegouz@yahoo.fr}

The notion of sustainable development consists mainly of innovating in order to keep the life cycle of the domain under study alive, by involving new requirements that will change the methods and practices of the various stakeholders. The construction sector, be it commercial or residential buildings, is also integrated in the sustainable development approach since its implementation until its exploitation by the occupants.

Several countries around the world, including Morocco, are engaged in the sustainable construction process to build energy-efficient buildings capable of offering thermal comfort, a considerable reduction in energy expenditure and a significant decrease in emissions. $\mathrm{CO} 2$ gas. The building sector is considered to be the most energy intensive and the second largest source of $\mathrm{CO} 2$ emissions after transport, these sources of energy consumption are divided into lighting, ventilation, air conditioning, heating, water hot sanitary, ...

A house with low energy consumption must be thought from its conception and it must submit to modifications of its energy behavior by the choice of its orientation, the types of energies used allow to limit the energy consumption (Solar, photovoltaic, ...) and also, by a judicious choice of innovative building materials evolved by building and civil engineering companies capable of providing thermal inertia in buildings, this is achieved either by incorporating new materials into the usual building products or by changing their basic formulas.

These materials are able to provide buildings with thermal inertia since they have a low thermal conductivity able to keep lime buildings in winter and cold in summer without resorting to other energy-consuming means namely ventilation and heating. 
IMAT3E'18

International Meeting on Advanced Technologies in Energy and Electrical

Engineering

In this context, several materials have been proposed by previous research and whose results were discussed. These materials are considered sustainable solutions to ensure thermal insulation of tomorrow. These insulating materials are either mineral, namely insulating panels based on natural basalt fiber, the use of pozzolan in building materials, etc. Or synthetic, such as corrugated cardboard panels recycled from packaging industries. Or, by valuing natural fibers as a reinforcement in building materials, namely: hemp fibers, flax, rapeseed, date palm wood, ...

The general objective of my thesis project is mainly to propose solutions to ensure a good thermal comfort to the buildings, this by the development of innovative building materials based on natural fibers and which are mainly the date palm leaflets which are very abundant in Morocco. In this context, several analyzes are possible on the leaflets and on the construction materials prepared in order to study their behavior vis-à-vis the energy efficiency in the buildings.

\section{References}

1. THE MANH D., Contribution to the development of precast hempcrete using innovative pozzolanic binder, PhD thesis, University of Toulouse 3 Paul Sabatier, 2014.

2. Cinzia B and All. Thermal and acoustic performance evaluation of new basalt fiber insulation panels for buildings. 6th International Building Physics Conference, IBPC 2015

3. F.Asdrubali and All, Innovative cardboard based panels with recycled materials from the packaging industry: thermal and acoustic performance analysis. 6th International Building Physics Conference, IBPC 2015

4. Jiří Z. and All, Development of Thermal Insulating Materials on Natural Base for Thermal Insulation Systems. 11th International Conference on Modern Building Materials, Structures and Techniques, MBMST 2013 